\title{
Development Of Agricultural Skill Program Using Task Analysis Approach For Students With Low Mental Retardation Level
}

\section{In Korpri School Pandeglang}

\author{
(Study of Tomato Cultivation with Polybag Media)
}

\author{
Haeriah, Tjutju Soendari \\ Special Education Department, School of Postgraduate Studies \\ Indonesia University of Education \\ Bandung, Indonesia \\ haeriahfaiq@gmail.com
}

\begin{abstract}
The obstacles in intellectual function and the inability to apply the adaptive behavior during development age may cause learning capacity problem even though their selfpotential should be developed, especially in basic skill. Based on that situation, it is important to provide children with low mental retardation level with self-learning skills, especially daily routine skills, to make them independent in their life. However, with the limitation they have, the learning process should be given step by step so that it is easily understood by students. The aim of this research is to formulate an agricultural learning program with a task analysis approach to study tomato cultivation using a polybag medium. It was conducted with a qualitative approach with the Research and Development ( $R$ \& D) method. The subjects of the first stage in this research were the Principal, one life skills teacher, three students with low mental retardation level. Additionally, the subjects of the second stage were 2 life skills teachers, three students with low mental retardation level. To obtain the research data, it was conducted through observation and interviews with the parties involved.The results of the study showed that the implementation of the program provides benefits and convenience for students with low mental retardation level in planting tomatoes in polybag media. As a program user, teachers are easier to convey the content of learning, to plan, to implement and to evaluate the success of the program.
\end{abstract}

Keywords—task analysis; agricultural skill; low mental retardation level.

\section{INTRODUCTION}

According to the American Association on Mental Retardation, intelligence rates for low mental retardation level children are from 52 to 68 according to Binet scale. While according to Wechler scale (WISC), it is about 55 to 70. With these intelligence figures, their learning capacity is limited, especially for abstract matters. They have problems in focusing attention, following instructions, tending to be shy, having lack of creativity and initiative, having limited vocabulary, and requiring long learning time. However, children with low mental retardation level are having the possibility to be taught basic academic skills such as reading, writing, and arithmetic. Therefore, to improve their creativity and independence, it is important to provide them basic skill learning.

As stated in the Education Unit Level Curriculum (KTSP) for SMALB, the allocation time for vocational skills lesson takes the most of the time. In addition, the direction of development is adjusted to the potential of the children and the potential of the area so that the determination of vocational skills depends on the school concerned. The general types of skills instructed by the KTSP curriculum include: agricultural skills, livestock skills, carpentry skills, office skills, and engineering skills.

Agriculture is a skill related to the efforts of fulfilling daily food needs. Agriculture is a very important sector in the national economy. In a narrow sense, agriculture is defined as a special production process based on the growth process of plants and animals [1]. While Reference [2] defines agriculture as an activity of maintaining plants and livestock on a plot of land, without causing the soil to be damaged for further production. Agricultural products are animate objects or living things such as rice, corn, fish, livestock, eggs and others.

Agricultural activities can be carried out by everyone. No exception for mentally retarded children. The progress of the industrial world has shifted agricultural land, as a result availability of land and people's interest in the agricultural world are getting narrower. On the other hand, the need for agricultural products increases with the increase of population. For this reason, SKh Korpri Pandeglang includes agricultural programs as learning programs at the SMALB level.

Through education in agricultural skills, it is hoped that it can form low mental retardation level children become 
independence and can actively participate in the environment in which they are located.

The author chooses the object of research through direct observation carried out at the Korpri School Pandeglang. It is because there are already a lot of agricultural products produced by students in SKh Korpri Pandeglang. For example, planting tomatoes, okra, sweet corn, chili, eggplant, cucumber, mustard greens and many more.

At SKh Korpri Pandeglang, researchers also found out the high enthusiasm of mentally retarded students in following the learning of agricultural skills. During the implementation of study in Korpri Skh Pandeglang SMALB, students including mentally disabled were given lesson of how to grow tomatoes. They are taught how to prepare farming tools, seeding, planting, taking good care of plants and also harvesting. In learning of planting tomatoes, they have been able to know and use agricultural tools commonly used in agriculture, for example hoes, earth diggers, plastic polybags, machetes, bamboo, buckets, and manure. They have also been able to process the land according to the teacher's instructions. But in fermentation works, sowing, weaning, transferring to large polybags, and applying fertilizer, they cannot do it independently. Teachers trusted this process done by deaf students because they are easier to understand than low mental retardation level students. Task analysis technique is applied as an approach for students with low mental retardation level as a special learning program that makes students able to do this activity. It is certainly taught with gradual techniques ranging from easy levels to difficult levels of how to grow tomatoes.

The theory [3] defines that task analysis is an effort to make details from one skill small tasks that allow students to easily implement it.

According to Reference, [4] "the benefits of task analysis techniques for teachers are:1). Providing guidelines to help students achieve their educational goals 2). Identifying learning problems. "In addition, teachers can use task analysis to record student progress in achieving educational goals. According to Reference, [4] there are two task analysis techniques that can be used, forward chaining and backward chaining methods.

\section{A. Forward Chaining}

Forward chaining is a teaching procedure in which instruction begins with the first step in the chain and proceeds toward the last step in the chain.

This approach involves teaching skills that begin with the first step, and then teach each step consecutively one by one until all skills have been learned. According to Doroty Popovich (1981: 88) this is very useful when a student has learned the initial steps of a sequence, and / or important skills learned in the next sequence. As an example; if the skill is students to be able to tie shoes, the first skill that will be targeted is to put their feet in the shoes. After the skill is acquired, students are expected to put their feet in their shoes, and tie the straps into bows.

\section{B. Backward Chaining}

Backward chaining is a teaching procedure in which instruction begins with the last step in the chain and proceeds toward the first step in the chain.

This approach involves teaching skills that begin with the last step, and then teach the previous steps before each other until all skills have been mastered. Doroty Popovich (1981: 89) suggests that one of the benefits of this method is that students succeed and independently complete skills that may be more motivating and intrinsically motivating. Skills such as zipping, preparing tables, and studying their landline numbers can all be taught using Backward Chaining. For example: for washing hands, the first skill that must be targeted is drying your hands. Once the skills are acquired, they will start to turn off the water independently and dry their hands. It is important to monitor student progress and always ensure that learning is taking place.

\section{METHOD}

The final product of this study is a learning program on farming skills to grow tomatoes for the mentally disabled students at SMALB level. The method applied in this research is Research and Development (R \& D) method. In accordance with the opinion of Reference [5], [6], which defines that research and development methods are methods used to produce certain products and test the effectiveness of these products. To be able to produce a certain product, it uses research which requires analysis and to test the effectiveness of these products so that they can function in the wider community. Research needed to test the effectiveness of these products. Researchers chose the method of research and development ( $\mathrm{R} \& \mathrm{D})$ with the intention of making an agricultural skills training program to grow tomatoes in polybag media that can be applied to all low mental retardation level students.

The approach in this study was qualitative. Researchers chose this model approach to reveal all that had been available and then to develop it into a program that could be used to improve the ability of agricultural skills in growing tomatoes using polybags for low mentally retarded students.

\section{RESULT AND DISCUSSION}

The aim of the study is to develop a learning program on agricultural skills for low mentally retarded students at the SMALB level with a task analysis approach. Program development focuses on mentally disabled students because the existing program is for all children with different problems. In this section, the researcher will describe the results of data collection carried out in SKh Korpri Pandeglang, especially the implementation of the learning process of agricultural skills in planting tomatoes in a poly bag for low mentally retarded children. Data retrieval conducted in this study includes observation, interviews and supported photo and video documentation on the implementation of agricultural skills in growing tomatoes with polybags for mentally retarded children. 
Factually, in agricultural skills learning, mentally disabled students do not get priority in learning agricultural skills. Usually, they only help or just prepare the tools that will be used in the process of farming and tillage and also in harvest time. In the nursery, planting and care sections such as mixing fertilizers are more trusted to be done by deaf students. This is because the teacher thinks deaf students are easier to understand instructions.

The researchers conducted an assessment and direct observation of three low mentally retarded students with the initials subject $1(\mathrm{Ww})$, subject $2(\mathrm{Rd})$ and subject 3 (Bgs) which are at level XI SMALB. The study was conducted by observing the agricultural skill activities of planting tomatoes with polybag media. The process begins with preparing agricultural tools, seed fermentation, seedling, weaning, planting into polybag, treatment and harvesting.

The skill program was structured through observation, assessment and validation by experts. The program refers to the National Education curriculum in 2006 by developing competencies tailored to the characteristics and potential of areas tailored to the students'. This program is made by considering the objectives, subject users and implementation procedures. The ultimate goal of the program is to realize independence for low mentally retarded students. The scope of agricultural learning starts from when students prepare agricultural tools, seeding, weaning, transfer into polybags, care and harvest. The subject of the user of this program is devoted to teachers of agricultural skills at SKh Korpri Pandeglang, and is expected to be able to be applied also by teachers in other schools that handle students with low intellectual disabilities.

In the trial program, the teacher as the program user felt the changes that occurred in the subject after being given an assignment based on the assessment carried out. The teacher felt some ease in using the program as a reference for low mental retardation level children. In this trial, the teacher gave agricultural learning to grow tomatoes which began by preparing agricultural tools. By introducing tools that they normally use everyday to tools that they rarely use, there are tools commonly used in agriculture introduced to them. For example: containers / bowls, tea strainer, scissors, buckets, hoes, sand, manure, urea, tray, spray, plastic polybags, plastic cakes, and calendars. From the three subjects, they were able to recognize the names of tools and function tools. In seed fermentation, the three study subjects began to sow the seeds to warm water until they were wrapped in patchwork and stored in a moist place for 24 hours. The three subjects were able to do it after being given an example by the teacher step by step. At the time of seed sowing, it begins with preparing the nursery equipment between the hands, manure, sand, and spray. Gradually, mentally retarded students were instructed to mix the seedling media with a ratio of two sand buckets and 1 bucket of manure then put it in the slap, and then spread the seeds that had been fermented for 24 hours. From the results of observations, students are able to seed based on the teacher's instructions. The seeding process took one week, the seedbed was stored in a humid room and was not exposed to direct sunlight until it became small shoots like sprouts. Furthermore, in the weaning process, students were taught step by step how to do weaning, which was, transferring the seedling media into a small polybag. During waiting for the nursery process, students were asked to prepare a small polybag made of plastic cake which was formed in polybags. This small polybag was filled with a mixture of soil and manure in a ratio of 2: 1 where two buckets of soil were mixed with one bucket of manure. In this weaning process, caution was needed because the sprouts could break and caused the sprouts to die. Of the three subjects observed, at the time of weaning, they had not been able to do it mandarially but they needed to be accompanied by the teacher. Because the process was long enough to move a lot of sprouts into polybags, sometimes saturation occured from mentally disabled students. The next process after the weaning process was the treatment by watering small polybags so as not to wilt. The weaning process was carried out for 14 days until growing sprouts had leaves for further being transferred into a large polybag. In planting into polybags, students were quite capable of doing it. Gradually, students were taught how to prepare polybags with a size of $5 \mathrm{~kg}$ filled with a mixture of soil with manure in a ratio of 2: 1 . In this transfer process, students were able to do it according to the teacher's instructions. Gradually, the teacher taught how to remove a small polybag and then put a small tomato into a large polybag and soil from a small polybag. The next thing was to take care the tomato, to give it fertilizer and to install the stakes (bamboo supports so the tomatoes grow up). ) In the treatment of plants such as watering, all subjects were able to do so. For installation, even students could do it after being given an example by the teacher, despite several attempts. As for fertilizing with a mixture of pearl fertilizer, students must be fully accompanied because of several attempts. Sometimes, they forgot the dose. Before the teacher gave instructions for mixing fertilizers, the teacher first explained the function and the process of how to use fertilizers and their danger to humans. Then, the teacher cited the use of two spoons of fertilizer dissolved into 10 liters of water. In practice, the teacher prepared a 10-liter bucket which was then mixed with two spoons of fertilizer. Furthermore, it was poured to the tomato plants using glass of used mineral water. The next stage was the harvest. In this stage, all subjects were able to do it starting from picking to sorting crops.

\section{CONCLUSION}

Through the trial process that has been carried out, it can be concluded that through the learning activities of this agricultural skill, low mentally disabled students are able to experience change and to increase their skills in agriculture specifically in tomato farming with polybag media through treatment carried out according to the research program. Thus, with continuous learning, guidance and training, it is believed that it can improve the ability and skills of low mentally retarded level students.

\section{REFERENCES}

[1] G. Satari, Pembangunan Pertanian dalam Milinium ketiga. Bandung: Orasi Ilmiah Fakultas Pertanian Universitas Padjadjaran, 1999.

[2] A. Rodjak, Pengantar Ilmu Pertanian. Yogyakarta: Graha Ilmu, 2012. 
[3] G. Harjanti, Panduan Pelaksanaan Kurikulum Pendidikan Khusus Sekolah Menengah Atas Luar Biasa Tuna Grahita ( Smalb-C). Jakarta: Depdiknas, 2006.

[4] D. Popovich, Effective Educational and Behavioral Programming for Severely and Profoundly Handicapped Student. London: Paul Brookes Publishing, 1981.
[5] Sugiyono, Metode Penelitian Pendidikan.pendekatan Kuantitatif, Kualitatif, and R\&D. Bandung: Alfabeta, 2013.

[6] M. A. Afrizal, Metode Penelitian Kualitatif. Jakarta: PT. Raja Grafindo Persada, 2014. 